DOI 10.37882/2223-2982.2021.09.24

\title{
СИСТЕМА СРЕДСТВ РЕЧЕВОЙ МАНИПУЛЯЦИИ В ПРЕДВЫБОРНОМ АГИТАЦИОННОМ ДИСКУРСЕ: НА МАТЕРИАЛЕ РЕЧЕЙ БРИТАНСКИХ ПОЛИТИКОВ
}

\section{THE SYSTEM OF MEANS OF SPEECH MANIPULATION IN THE DISCOURSE OF THE ELECTION CAMPAIGN: BASED ON THE SPEECHES OF BRITISH POLITICIANS \\ O. Petrukhina T. Koroleva I. Djachenko}

Summary: In the framework of modern linguistic paradigm, researchers are particularly interested in studying various means of speech manipulation in political election discourse aimed at influencing the audience. The analysis of the examples showed the effectiveness of using promissive speech acts to achieve this goal. A comprehensive study of promissive speech acts in political discourse, when analyzing their communicative and pragmatic properties, allows us to study in more detail the promissive intention of a politician and the procedures of linguistic and pragmatic analysis.

Keywords: the discourse of the election campaign, speech manipulation, strategy, speech act, promissive intention.

\author{
Петрухина Оксана Петровна \\ К.филол.н., ФГБОУ ВО «Хакасский государственный \\ университет им. Н.Ф. Катанова» \\ Petrukhina1@yandex.ru \\ Королева Татьяна Александровна \\ К.филол.н., дочент, ФГБОУВО «Хакасский \\ государственный университет им. Н.Ф. Катанова» \\ Дьяченко Ирина Александровна \\ К.филол.н., ФГБОУ ВО «Хакасский государственный \\ университет им. Н.Ф. Катанова»
}

Аннотация: В рамках современной лингвистической парадигмы особый интерес для исследователей представляет изучение различных средств речевой манипуляции в политическом предвыборном дискурсе, направленных на воздействие аудитории. Анализ примеров показал эффективность использования промиссивных речевых актов для достижения данной цели. Комплексное исследование промиссивных речевых актов в политическом дискурсе при анализе именно их коммуникативно-прагматических свойств позволяет более детально изучить промиссивную интенцию политика и процедуры лингвистического и прагматического анализа.

Ключевые слова: предвыборный агитационный дискурс, речевое манипулирование, стратегия, речевой акт, промиссивная интенция.
$\mathrm{B}$ современных исследованиях политического дискурса на первый план выходят проблемы, связанные с речевым манипулированием. Конструирование речевого манипулирования имеет вид стратегического процесса, в основе которого лежит выбор политика языковых средств и речевых стратегий, обеспечивающих необходимую для адресанта реакцию адресата.

Многие исследователи-лингвисты дают определение речевому манипулированию как процессу, в основе которого лежит воздействие на эмоции слушателя. Данный процесс они противопоставляют другому, который направлен на изменения в сфере логики и сознания реципиента.

Как считает О.С. Иссерс, «если убеждение осуществляется преимущественно с опорой на сознание, разум реципиента, то внушение - с опорой на эмоции. Внушая определенную мысль, субъект речевого воздействия апеллирует, прежде всего, к эмоциям объекта речевого воздействия, стремясь тем самым привести его в нужное для целей говорящего психологическое состояние» [4: 38].

Г.Г. Почепцов рассматривает речевое воздействие в перлокутивном аспекте, в связи с чем анализируются следующие реакции со стороны адресата:

1. изменение отношения к какому-либо объекту, изменение коннотативного значения объекта к субъекту (выражается в призывах, лозунгах);

2. формирование общего эмоционального настроя (политическое воззвание);

3. перестройка категориальной структуры индивидуального сознания, введение в неё новых категорий (цит. по Иссерс 2003: 23). Большую значимость для результатов речевого воздействия играет такой фактор, как положительный эмоциональный настрой аудитории.

Раскрывая параметр скрытости/открытости воздействия, В.И. Карасик разграничивает убеждение (аргументацию) и манипуляцию [6: 157]. По словам Е.И. Шейгал, убеждение в политическом дискурсе «связывается преимущественно с воздействием на эмоции и подсознание, а не на разум, логическое мышление» [20: 56].

С целью обнажения приемов воздействия на сознание в политических текстах появилось множество лингвистических работ, внимание в которых было сосредо- 
точено на выборе номинаций и грамматических форм, скрытых и подразумеваемых предпосылок, смене ярлыков и искажении причинно-следственных отношений, принципах порождения идеологизированных текстов.

Ряд ученых рассматривают манипуляцию как разновидность аргументации, которую в свою очередь подразделяют на два вида:

1. логическая аргументация - аргументация, направленная на «обоснование и расширение достоверного знания на основе принимаемой субъектом аргументации совокупности логико-гносеологических процедур»;

2. прагматическая аргументация - аргументация, в которой используют все возможные средства для создания у реципиента мнения [14: 12].

Изучение работ по феномену речевой манипуляции позволяет сделать вывод о подходе, который можно обозначить как «тактико-стратегический» [1]. Ключевыми категориями при подобном подходе к изучению речевой манипуляции в политическом дискурсе становятся понятия «тактики» и «стратегии».

В лингвистике рассматриваются различные речевые тактики и стратегии, применяемые политиками в ходе воздействия на сознание и эмоции массового реципиента. Стратегии, как совокупности целенаправленных действий в модели порождения и понимания дискурса, могут быть по-разному интерпретированы по своей природе. Выделяются пропозициональные (ван Дейк 1988), речевые (Иссерс 2003), коммуникативные стратегии (Михалёва 2005; Карасик 2004; Паршина 2007), дискурсивные стратегии (Плотникова 2006) и др.

О.С. Иссерс под речевой стратегией понимает «комплекс речевых действий, направленных на достижение коммуникативной цели» [4: 54]; О.Л. Михалёва под коммуникативной стратегией рассматривает «план оптимальной реализации коммуникативных намерений, учитывающий объективные и субъективные факторы и условия, в которых протекает акт коммуникации и которые в свою очередь обусловливают не только внешнюю и внутреннюю структуру текста, но и использование определенных языковых средств» [7: 45].

О.Н. Паршина определяет коммуникативную стратегию «как сверхзадачу речи, диктуемую практическими целями говорящего», как «определенную направленность речевого поведения в данной ситуации в интересах достижения цели коммуникации» [9: 10-11]. Согласно классификации по Аристотелю, у политика есть намерение:

а) побудить адресата проголосовать на выборах за определенного кандидата, партию, блок;

б) завоевать авторитет или укрепить свой имидж, «понравиться народу»; в) убедить адресата согласиться с говорящим, его мнением, принять его точку зрения;

г) создать определенный эмоциональный настрой, вызвать определенное эмоциональное состояние адресата;

д) дать адресату новые представления о предмете речи, информировать адресата о своей позиции по определенному вопросу [23].

Несмотря на небольшие расхождения в исследовании основных понятий тактико-стратегического подхода в различных видах дискурса, в том числе и политического дискурса с доминирующей манипулятивной интенцией, основной подход данных исследований заключается именно в описании речевых тактик и стратегий, выделенных на основе анализа материала. Соответственно, и комплексы тактик и стратегий, анализируемых исследователями, достаточно разнообразны [Г.В. Грачев, О.Н. Паршина, О.Н. Михалева, С.Г. Кара-Мурза, Е.И. Шейгал и др].

Речевое манипулирование представляет собой процесс взаимодействия интенций открытого и скрытого типов, реализующихся в соответствующих речевых актах. В качестве речевых актов открытого типа могут выступать речевые акты (промиссивы, декларативы, ассертивы, экспозитивы и директивы), описанные в традиционной теории исследования по данному вопросу [15].

Исследование показывает, что доминирующей интенцией открытого типа в британском предвыборном агитационном дискурсе является интенция обещания, а средством ее реализации, соответственно, промиссивный речевой акт. В рамках реализации отдельных речевых интенций, объектами которых являются обещание и заявление, политик реализует три основные интенции: информативная, собственно коммуникативная и персуазивная.

Используемый политиками глагол to promise является ядром класса промиссивов. Однако стоит отметить, что интенция обещания может быть выражена с помощью других промиссивных глаголов. Практически все члены синонимического ряда глагола to promise можно отнести к промиссивным иллокутивным глаголам, которые несут в себе функцию обещания и используются для эксплицитного выражения промиссивного намерения [1].

Проиллюстрируем эту последовательность примерами. ...And this new Labour government will govern in the interests of all our people - the whole of this nation. That I can promise you. So again I can promise you. When I became leader of the Labour party some three years ago / set a series of objectives. By and large I believe we have achieved them. Today we have set objectives for new Labour Government - a world class education system. Education is not the privilege of the few but the right of the many. 
(Blair's speech at 10 Downing Street, May 2, 1997, (http:// www.britishpoliticalspeech.org)

В данном микротексте реализуются следующие акты промиссивной речевой интенции у Т. Блэра:

1. I can promise you - модально-интенциональная перформативная формула, которая содержит модальный глагол can. Данный глагол указывает на способность политика брать на себя определенные обязательства;

2. And this new Labour government will govern in the interests of all our people - the whole of this nation - информативный компонент, который передает обещаемые события;

3. I can promise you ... So again I can promise - персуазивный компонент, который выражается с помощью модально-интенциональной перформативной формулы с маркером повтора (again).

Рассмотрим фрагмент речи Дэвида Кэмерона, в котором премьер-министр Великобритании сопровождает акт обещания определением условий, при которых возможно совершение действий, отраженных в пропозиции:

Giving people the right to fire their MP... The plans in these pages have the potential to be era-changing, to end the age of state power and bring in a new age of people power. I promise you: if we achieve even half of our ambitions, it will be the biggest change in how the country is run for more than a generation.

(David Cameron: Welsh Manifesto launch, http://www. conservatives.com)

В данном выступлении, опираясь на прототипическую оценку (the age of state power), лидер консервативной партии имплицирует, что, придя к власти, партия будет работать для народа, в руках которого находятся все права на улучшение своего благосостояния (age of people power). Данный промиссив имеет форму сложноподчиненного предложения с придаточным условия if. Эти условия (if we achieve even half of our ambitions) необходимы для совершения действия, которое считается как обещаемое (it will be the biggest change in how the country is run for more than a generation).

Наличие промиссивной интенции в качестве доминирующей и, соответственно, большое количество различных по структуре представленных компонентов речевых актов обещания содержится в следующем фрагменте выступления премьер-министра Т. Блэра:

... Our mission in politics is to rebuild this bond of trust between government and the people (1). That is the only way democracy can flourish. I pledge to Britain a government which shares their hopes, which understands their fears, and which will work as partners with and for all our people, not just the privileged few (2). This is our contract with the people.
(Britain will be better with new Labour (http://www.labourparty.org.uk/manifestos/1997/1997-labour-manifesto.shtm)

При анализе данного высказывания в терминах стандартной теории речевых актов мы имеем два речевых акта, соответственно две пропозиции и две иллокутивные силы. Перформативная формула представлена ассертивом 1, а содержание обещания в промиссивном акте 2 заключается в глаголе to pledge, представленном пропозицией, реализующей информативную интенцию говорящего (which will work as partners with and for all our people, not just the privileged few). Обещание представлено эксплицитно британским политиком, Т. Блэр пытается убедить аудиторию в том, что правительство Британии будет работать для всех жителей страны for all our people.

Но политик имплицитно выстраивает следующие равные эквиваленты: "Britain" = "government" = "people" = "our", где эти слова взаимо заменяются. Можно с лёгкостью реконструировать предложение, не изменяя его значения: "I believe in us (government), in the British people and our capacity to be the partners ...."

Считается, что следствием совершения речевых актов обещаний может быть проявление каких-либо положительных чувств и эмоций со стороны того, кому непосредственно адресуется обещаемое политиком действие, а именно: радость, благодарность, чувство внутреннего удовлетворения и покоя. Но положительные эмоции как перлокутивный эффект могут возникнуть у слушающего лишь в том случае, если обещаемое ему совершение какого-либо действия является для него желательным (подобные речевые акты являются, собственно, промиссивными). Например:

Only by voting Conservative can you vote for no nonsense action in the fight against crime. And I promise you this: I'll get the job done.

(Michael Howard: Our hope is for a better Britain, http://www.conservatives.com)

Используя лексику с отрицательной коннотацией: «fight», «crime», «nonsense action» лидер Консервативной партии вызывает у слушателей отрицательные эмоции - страх, тревога и беспокойство. Но, наряду с отрицательной присутствует промиссив, который несет в себе положительную коннотацию, вызывающую уверенность и защищенность жителей. Промиссив I promise you this: I'll get the job done имплицирует, что консерваторы, придя к власти, будут бороться против преступления и наведут порядок в стране. Противоречивость данных пропозиций используется в конкретной ситуации, требующей выяснение взглядов, позиций и намерений политика.

На основании проанализированных примеров, можно сделать вывод об эффективности использования 
промиссивных речевых актов для достижения цели, направленной на воздействие аудитории. Прагмалингвистический анализ промиссивных речевых актов в поли- тическом дискурсе позволяет выявить и более детально изучить промиссивную интенцию политика и процедуры лингвистического и прагматического исследования.

\section{ЛИТЕРАТУРА}

1. Антонова А.В. Система средств речевой манипуляции в британском политическом дискурсе: реципиентоцентрический подход. Текст.: дисс. . канд. филол. наук / А.В. Антонова. Самара. - 2011. - 386 с.

2. Грачев, Г.В., Мельник, И.К. Манипулирование личностью: организация, способы и технологии информационно-психологического воздействия Текст. / Г.В. Грачев, И.К. Мельник. М.: Институт философии РАН, 1999. - 235 с.

3. Дейк, Т.А. ван. К определению дискурса Электронный ресурс. - Режим доступа: http://www.nsu.ru/psych/iternet/bits/vandijk2.htm (Дата 0бращения: 22.06.2021)

4. Иссерс, 0.С. Коммуникативные стратегии и тактики русской речи. Изд. 3-е, стереотипное Текст.: монография / 0.С. Иссерс. М.: Едиториал УРСС, 2003. - 284 с.

5. Кара-Мурза, С.Г. Манипуляция сознанием Текст. / С.Г. Кара-Мурза. - М.: Эксмо, 2006. - 832 с.

6. Карасик, В.И. Язык социального статуса Текст. / В.И. Карасик. М.: Гнозис, 2002. - 333 с.

7. Михалёва, 0.Л. Политический дискурс. Специфика манипулятивного воздействия Текст: монография / 0.Л. Михалева. М.: Книжный дом «ЛИБРОКОМ», 2005. -256 c.

8. Остин, Дж. Слово как действие Текст. / Дж. Остин // Новое в зарубежной лингвистике. М.: Прогресс, 1986. - Вып. 17. - с.22-131.

9. Паршина, 0.Н. Российская политическая речь: Теория и практика Текст. О.Н. Паршина / Под ред. О.Б. Сиротининой. Изд. 2-е, испр. и доп. - М.: Издательство ЛКИ, 2007. -232 с.

10. Паршин, П.Б. Понятие идиополитического дискурса и методологические основания политической лингвистики Электронный ресурс. Режим доступа www.elections.ru/biblio/lit/parshin.htm. (Дата обращения: 26.02.2021)

11. Плотникова, С.Н. Стратегичность и технологичность дискурса [Текст] / С.Н. Плотникова. - Иркутск: Вестник ИГЛУ, 2006. - №3. - С. 87 - 98.

12. Почепцов, Г.Г. Имидж и выборы. Имидж политика, партии, президента Текст. / Г.Г. Почепцов. Киев, 1997. - 140 с.

13. Седов, К.Ф. 0 манипуляции и актуализации в речевом воздействии Текст. / К.Ф. Седов // Проблемы речевой коммуникации: Межвуз. сб. науч. тр. Саратов: Изд-во Сарат. ун-та, 2003. - Вып. 2. - с.20-27.

14. Сергеев, В.М. Когнитивные методы социальных исследований Текст. / В.М. Сергеев // Язык и моделирование социального взаимодействия. М: Прогресс, 1987. - c.3-20.

15. Серлъ, Дж.Р. Классификация иллокутивных актов Текст. / Дж.Р. Серль. // Новое в зарубежной лингвистике. М.: Прогресс, 1986. - Вып. 17. - с.170-195.

16. Серлъ, Дж.Р. Косвенные речевые акты Текст. / Дж.Р. Серль. // Новое в зарубежной лингвистике. - М.: Прогресс, 1986. Вып. 17. - с.195-283.

17. Серль Дж. Что такое речевой акт? Текст. / Дж.Р. Серль.// Новое в зарубежной лингвистике. М.: Прогресс, 1986. - Вып. 17. - с.151-169.

18. Стернин, И.А. Введение в речевое воздействие Текст: Монография / И.А. Стернин. Воронеж, 2001. - 252 с.

19. Чудинов, А.П. Метафорическая мозаика в современной политической коммуникации Текст: монография / А.П. Чудинов. Екатеринбург, 2003. - 248 с.

20. Шейгал, Е.И. Семиотика политического дискурса Текст: монография / Е.И. Шейгал. Ин-т языкознания РАН; Волгогр. гос. пед. ун-т. Волгоград: Перемена, 2000. $-368 \mathrm{c}$.

21. Aristotle On Interpretation / Translated by E.M. Edghill Электронный ресурс. Режим доступа: http://classics.mit.edu/Aristotle/interpretation.html (Дата 06ращения: 16.07.2021)

22. Dijk, T.A. van. Ideology: A Multidisciplinary Approach Text. / T.A. van Dijk. London: Sage, 1998. - 384 p. 